\title{
Problems of the Russian Economy
}

\section{Chapluk Vladimir}

Peoples' Friendship University of Russia, Department of accounting and statistics

\section{Andryushchenko Galina}

Russian State Social University, Faculty of Social Insurance Economics \& Sociology of Labor Department of Social Insurance, Economy and Sociology of work

\section{Sorokina Larisa}

Russian State Social University, Faculty of Social Insurance Economics \& Sociology of Labor, Department of Finance and Credit,

\section{Kukharenko Olesya}

Russian State Social University, Faculty of Social Insurance Economics \& Sociology of Labor, Department of Finance and Credit,

\section{Petrovskya Maria}

Peoples' Friendship University of Russia, Department of accounting and statistics

\section{Doi:10.5901/mjss.2016.v7n3p206}

\begin{abstract}
In the article the problems of Russian economy under economic sanctions are studied. The economy growing thanks to hydrocarbon exports depends on the prices in the international energy market. Whilst falling oil prices induce the economic slowdown. Lack of proper investment in the restructuring of scientific and technological potential in different sectors of the economy reduces the quality indicators of GDP. Therefore, enhance of economic growth and solution to the import substitution problems is crucial for the transition from the export of raw material to the intensive development.
\end{abstract}

Keywords: financial crisis, economic integration, economic growth, economic sanctions, innovative production, technological development, asset-intensive production, material and technical base, restructuring.

\section{Introduction}

\subsection{Introduction to the Problem}

There have been structural changes in the proportions of public production under the conditions of Russian market economy formation. The result was an industrial production reduction and expansion of hydrocarbons exports. Simultaneously, Russian economy has become largely dependent on external markets. The global financial crisis has negatively influenced the inflow of investments into the Russian economy resulting in a GDP growth slowdown. Defining development priorities, the Russian economy began to gradually emerge from the crisis. The world economy has not yet fully overcome the consequences of the financial crisis. The developed countries, at the expense of developing countries, are intensifying sale markets. Thus, the United States, identifying weak points of investments in Russian economy, imposed the economic sanctions on Russia. These economic sanctions have not only weakened Russian economy but also have slowed down the public sphere. The problem of economic stagnation roots in inefficiently invested into large non-productive investment projects funds, accordingly investment processes do not activate real economy. This article contains both a retrospective analysis and perspective, which is based on a realistic forecast of socio-economic development of the Russian Federation until 2020. 


\subsection{Disclosure of the Importance of the Problem}

The development of the Russian economy is mainly based on the export of hydrocarbons. The financial crisis, Western sanctions, the devaluation of the ruble have negative impact on the Russian economy. In addition, the fall in oil prices has led to the reduction in investments and consumer demands whereas capital outflows continues. The economic growth in 2013 was 1.4\%. It was the lowest level since the financial crisis of 2009 and 1998. (Daily Finance Journal, 2014, January 30) According to the analysts, the results of 2014 can be zero growth in the economy. (INTERFAX.RU, 2014, April 15). Western countries have pushed Russia out of world markets. As a result, Russia is forced to look for new forms of economic integration with neighboring countries which will reduce the economic and political dependence on the US and the EU.

\subsection{Description of the Research in this Area}

According to the economic theory, the economic development is associated with economic growth, nevertheless, growth not always characterizes the economic development. Russian economic growth without development in 2000-2008 mainly depended on the sale of hydrocarbons. The absence of effective state industrial policy has negatively contributed to ineffective investments into large non-productive investment projects. The government did not increase investment processes in the real economy. To overcome import dependence, the innovative production is required. In order to attract investment in the manufacturing sector there is the need to develop state investment policy of accumulating financial resources into public production.

\section{Methodology}

\subsection{Definition of the Object of Research}

The object of this article was chosen the following elements of the economy, such as industry, investment, innovative production. Today difficult phenomena are happening in the economic life of Russia, due to the threat of a new financial crisis, as well as numerous unresolved social and economic problems. The main link of the economy is the industry. When industrial enterprises are creating innovative products, they form the real revenues of the federal budget. That's why the study of the problems associated with the economy development in conditions of instability is an important task.

\subsection{Determination of its Key Features}

The following characteristic problems affecting the development of the Russian economy: financial crises, economic sanctions, expanding economic space, the structure of public production, attraction of investments into the real sector of the economy, the creation of innovative productions able to implement import substitution are discussed in this article.

\subsection{The Choice of Study Method}

The article used the following research methods. Historical and logical methods were used to study the problems in the development of the Russian economy. They allowed us to estimate the negative trends affecting the economic processes in their historical sequence and made it possible to draw general conclusions. The method of analysis and synthesis helped to study to economic phenomena by parts and as a whole. The combination of analysis and synthesis provided a systematic approach to the objects of study. Abstraction method was used for cleaning of the test subject from the particulars. Methods of comparison, grouping and summarizing helped to analyze the practical data, changes in research facilities, to identify trends and patterns of development.

\section{Results}

\subsection{Set of the Analyzed Data}

In order to obtain reliable results of the study, the authors analyzed the statistics of industrial production in the developed countries. The analysis of the indicators characterizing the state of the global economy was done. The initial data for the analysis are presented in the official media websites, based on the publications of the International Monetary Fund, the operational statistics of the European Union, scientific works of modern economists in the field of economy. 


\subsection{Initial Data}

The analyzed original data are sufficiently verified as mainly represented by the Russian legislation, static data of official state structures, the statistical office of the European Union, International Monetary Fund data. The analysis was made on the basis of both retrospective and prospective data. The analyzed data are based on the legislation of the Russian Federation, official statistics state structures, the statistical office of the European Union, International Monetary Fund data. The assay is based on retrospective and prospective data.

\subsection{Statistics and Analysis}

The formation of the results of the study had a significant impact on static analysis of data characterizing the dynamics of industrial production in developed countries. The rate of change of the parameters under study was analyzed, the level of world development production was determined. The analysis of the problems affecting the development of the Russian economy allowed the authors to determine the factors contributing, in the long term, to strengthening the innovation process in the real economy, and due to the formation of innovative industries to solve the problem of import substitution.

\section{Discussion}

\subsection{The Main Problems of the Russian Economy}

The main problems of the Russian economy are: reduction of investments in the Russian economy due to the global financial crisis and the Western economic sanctions; reduction in GDP growth; inflation; the slowdown in production and incomes in the public sphere; creating an innovation policy to enhance domestic investment in the real economy; the development of innovative industries to ensure economic growth.

The global financial crisis, the economic sanctions are imposed not only in order to weaken the Russian economy, but also to slow down the development of the public sphere. In addition, the fall in oil prices at the beginning of 2015 provoked the fall of the ruble, led to higher inflation and caused economic and social decline. Under the conditions when the United States through the European Union are at competitive war with Russia for the European markets, Russia should seek other ways of global integration. Therefore, under current conditions, the strategy of the Russian economy development is linked to the prospect of the development of the Customs and the Eurasian Economic Union. These forms of economic integration develop a united economic space, which will reduce the economic and political dependence on the US and the EU.

In addition, the monetarist dogma theory, imposed on the Russian economy, still hinders the economic development of Russia. It is realized everywhere that only through investment, the global economic crisis can be overcome. The dogmatic application of monetary theories and economic models, containing recommendations on how to ensure economic growth, recedes into the background. If previously, the steady growth of self-regulatory capacity of capitalism was linked to the "invisible hand" of the interaction of personal interests, at present, the understanding of the need for government intervention into the processes of economic development comes out.

The world economy is still in effect of cyclical development model (Seleznev A.Z., Chaplyuk V.Z., 2012). The cycles are realistic. It is considered that the economic cycle consists of four phases which are differently called by various researchers. Marxists allocate crisis, depression, revival and rise. P.-E. Samuelson uses such terms as compression, revival, expansion, top. Karl Marx believed that crisis was a strong remedy smoothing conflict economy for a while. Achieving the reduction in business activity, the crisis creates a new equilibrium on the basis of which this activity can once again gain strength.

Therefore, under the present conditions, the reality in developed economies has engaged active involvement of the state into the reproduction processes, the development and strengthening of its economic functions. Even so, the financial crisis has not contributed to strengthening of innovative technologies. Only the infusion of capital into the banking sector intensified manufacturing for some time.

In addition, despite the measures taken to overcome the crisis, the United States and the European Union have difficulty in enhancing the growth of industrial production (Table 1) (Annual Report IMF, 2014). And the introduction of sanctions contributing to oust the Russian economy from the European and American markets adversely affects the pace of economic recovery of the European Union. The developed countries have not yet overcome economic and financial factors that led to the global financial crisis. As a result, in the short term, the global economy is waiting for a new and more protracted financial crisis. 
These table data describe the dynamics of industrial production of the leading countries of the world. The positive output growth in 2010 was observed in all the analyzed countries. Thus, the increase in Japan was 15\%, 11.6\% in Germany, 5.7\% in the USA. Beginning from 2011, first during the analyzed period, the negative dynamics of production growth began to show, particularly, in two technologically advanced countries, in the UK $-1.2 \%$ and $-2.9 \%$ for Japan. Then the production decline continued in 2013. In Japan to - 0.9\%, France to - 0.9 to -3.1 in Italy, in Germany, $0.3 \%$, $2.9 \%$ in the US. Higher average annual growth in industrial production in the United States amounted to $-4.4 \%$, in Russia $4.1 \%$, the lowest $0.4 \%$ in Italy. This indicates that Russian industry during crisis is less exposed to downturn than Western ones. The Russian economy has sufficient potential not only to respond to crises but also to recover quickly under sanctions.

The experience has shown that while in the economies of the developed countries the development of new technologies does not appear and proceed, and the energy belongs to the developing countries and, thus, there is constantly growing competition between them, furthermore, these countries provide economic aggression against competitors, as a result of this, the country's economy becomes dependent on the competitor in these countries. This allows the developed countries to step up business activity and postpone the crisis for some time. It is this way, due to political and economic plunder of the Soviet Union, the European Union was formed. Thanks to the post-Soviet states in 90th the United States not only avoided the economic crisis but strengthened global economic dominance.

During the last decade of the twentieth century, the well-known economists, under the leadership of the United States, transferred the Soviet planned economy into a market economy. At the same time, there were made structural changes in the proportions of public production. The industrial structure was changed but not in the direction of its proximity to the structures of the industrialized countries, just the opposite, to worse. That led to the transformation of Russia into a raw materials appendage of the developed economies. (Chaplyuk V.Z., Karagod V.S, 2012). The reformed at the behest of the United States, the Russian economy in 1998 showed the ability to create a "financial bubble" at the stock markets, to inflate the fictitious capital, without changing anything in the real economy. The approach of this kind provokes a financial crisis, which itself does not always form a cyclical development of the economy.

A key factor in the slowdown of economic growth is the unfavorable situation in the market of commodities prevailing in the Russian export. An increase in production happens only due to the public sector - the state increases the incomes of state employees, regulates the laws.

Nevertheless, in 2008 there was a decline. It was caused by the fact that the state invested funds inefficiently into the large non-productive investment projects, investment processes were not activated in the real sector of the economy including agriculture, it did not develop properly the livestock. As a result, import substitution developed into a difficult problem which solution was not provided by budgetary funds.

Market economy in its development cannot be based only on the extension of the state demand and budget support. The sources of economic growth are to be found in the private sector. To provide this, it is crucial to stimulate small and medium businesses. State financial support should be carried out only on the financing of industrial enterprises capable of producing competitive investment products. At the same time, the government should introduce higher requirements on technical characteristics of products that allow to compete with the imported goods (Chaplyuk V.Z., 2011). The revitalization of manufacturing business will increase employment, saturate the market with domestic goods and provide real economic growth.

Due to the fact that the potential of the Russian economy is based on the sale of raw materials, the financial crisis for Russia has more serious consequences than for the developed countries. During the 2008 crisis, the price per barrel fell to 134.67 dollars, and in 2014 - from 108.48 to $57 \$$ per barrel, accordingly. The rapid development of the financial structure and more flexible use of loans are the main levers, the use of which contributes to overcoming the recession. In this regard, in 2014, to increase the capitalization of Russian banks DIA ("Deposit Insurance Agency") is selected. To weaken Russia economically and cause significant damage to the economy, the US imposed economic sanctions aimed purposefully at reducing the financial sphere. The United States, together with the European Union, limited access of Russian banks to their foreign currency loans and, thereby, contributed to the rapid accumulation of contradictions in the financial sector through a sustained weakening of the Russian ruble.

The increased demand for currency liquidity and its failure to handle the foreign exchange market brought down the rate of the ruble against the currency exchange rates. Low ruble provoked inflation, declining living standards, forced to reassess corporate bonds, government bonds declined, resulting in the bank's capital decline. (Chaplyuk V.Z., 2011). Thus, instead of the progressive development of the economy, the Russian government was forced to seek the ways to overcome the financial obstacles, to take measures of improvement the exchange of refinancing of banks, to develop economic measures of overcoming the American and European sanctions.

At the same time one of the obligatory conditions for the successful functioning of the economy as a whole, as well 
as one of the most important spheres of activity of any business entity is an investment activity. The production process is continuously transforming both- in the part of replacing of outdated forms and in the part of the extension of new forms and methods of production. Therefore, the purpose of investing is to achieve specific predefined effect.

The transformation of economic resources into an economic product has a certain time lag. Manufacturers have, first, to acquire the necessary resources to carry out certain costs, to divert this money to create factors of production and to obtain the desired result- the return on investment. At the enterprise level the priority target of investment is to achieve, as a rule, economic benefits that can be obtained in the form of growth in the amount of capital investment, the positive value of the investment revenue, positive net cash flow, ensure the preservation of the previously invested capital.

The involvement of the accumulated capital into the economy is the most active form of investment process. The tight connection with the accumulation of capital investments (savings) is an important component for economic growth. This relationship was emphasized in the December Presidential Speech (2014.) (Russian Newspaper, 2014, December 15). The FNB will invest in infrastructure projects. In our opinion, the intensification of the investment process must be started with a market institutional environment which plays the first role in improving production technologies (material and non-material) and changes in economic relations (under the competition).

The practice of dividing investments into real and financial, in the terms of the investment, is appropriate to consider at the micro and macro levels. The investment process at the micro level should be viewed as dynamic real investments that contribute to the change of forms of capital investment by the successive transformation of resources or values in real assets (fixed assets and intangible assets), followed by the conversion of investments into revenues or social effect. At the macroeconomic level, the government should seek to develop and implement the investment policy, to increase the volume and efficiency of real investment and financial ones should be regarded as one of the sources of funding.

When investing state funds into the industry of the enterprise it is necessary to consider the most important criteria for the renewal of production. That is, it is essential to take into account the types of industries while investing capital.

For example, for the operation of facilities requiring heavy funds (asset-intensive production) the main production factor is the non-current assets: land, buildings and facilities. These are mainly large steel and shipbuilding plants, agricultural production, transport and construction. The main share of the costs of enterprises of these industries account for funds: depreciation plus the cost of maintaining their technical condition. And almost all of these costs are ongoing. (Chaplyuk, 2013) Asset-intensive production is focused on long-term fund-raising volume of foreign investments. Much material- consuming manufacture of the biggest share of their expenditures are used to purchase raw materials and components. These financial costs are largely dependent on seasonal fluctuations of supply and demand. The method of financing such activities is carried out at the expense of own and borrowed funds.

Growing investment activity of the state in the real economy must be subordinated to increase production efficiency. It is essential to involve elements of state investment policy: investment cost, depreciation, tax, fiscal, monetary control.

\section{Conclusion}

The review of specific problems of the Russian economy was made in the article. The retrospective is presented by 20082014. The reduced to zero index of economic growth in 2014 is largely due to the mismanagement of economic processes. The stake on revenues from the sale of hydrocarbons on the world markets leads to economic stagnation. Beside economic sanctions, falling oil prices led to a decrease in investment in the economy. To develop the economy it is important to restore the structure of public production, in accordance with the structures of the industrialized countries, as soon as possible, to make the transition from the economy of the state raw material export type of development to intensive development. When the international investments in the economy are limited new approaches to financing industrial enterprises are required. Investments in the industry of the enterprise should go to the renovation and creation of innovative productions.

The package of measures designed to "move the country's economy from the export of raw materials development to intensive development", first, in the system form was provided by the adoption on December 31, 2014, the Federal Law "On Industrial Policy of the Russian Federation №488-FZ (2015, April 16).

These measures include:

- provision of state and municipal preferences to the enterprises producing products having no analogs;

- financial support of stakeholders in the industry in the form of budget subsidies, taking into account the state of individual industries, as well as in the form of tax benefits;

- establishment of the industry development funds on the basis of state budget to provide grants, loans, capital 
contributions, for financial lease (leasing);

- making special investment contracts;

- taking into account the spatial development strategy of the Russian Federation the creation of new and development of old industrial clusters.

\section{References}

Annual Report of International Monetary Fund (IMF) for 2013, April 2014. doi: http://www.imf.org/external//russian/index.htm Federal Law "On Industrial Policy of the Russian Federation №488-FZ. (2015, April 16).

Seleznev A.Z. Chaplyuk V.Z. (2012). The contradictions of the budget system of Russia. Journal «Finance and Credit», 44 pp. 2-10.

Chaplyuk V.Z. (2011). Background innovative development. Journal of the Economist, 4, pp.. 38-39.

Chaplyuk V.Z. (2013). Problems of formation of the technological structures of production. Bulletin of the Russian Peoples' Friendship University № 4, Moscow, 105.

Chaplyuk V.Z., Karagod V.S. (2012). Problems of economic development of the modernized Russian economy. Bulletin of the Russian People's Friendship University, 3. pp. 28-34.

Daily Finance Journal (2014, January 30). doi: http://daily-finance.ru/articles/2014-01-30/df/30039

INTERFAX.RU (2014, April 15). doi: http://www.interfax.ru/business/371694

Message from the President of Russia. (2014, December 15). Russian Newspaper. doi: www.rg.ru.

Table 1. Dynamics of industrial production, increase (decrease) in\% to the previous period (Annual Report IMF, 2014)

\begin{tabular}{|l|c|c|c|c|c|}
\hline & $\mathbf{2 0 1 0}$ & $\mathbf{2 0 1 1}$ & $\mathbf{2 0 1 2}$ & $\mathbf{2 0 1 3}$ & Average annual growth rate \\
\hline Russia & $\mathbf{7 , 3}$ & $\mathbf{5 , 0}$ & $\mathbf{3 , 4}$ & $\mathbf{0 , 4}$ & 4,1 \\
\hline Brazil & 10,2 & 0,4 & $-2,3$ & 2,1 & 1,2 \\
\hline Germany & 11,6 & 8,8 & $-0,6$ & 0,3 & 3,2 \\
\hline India & 9,7 & 4,8 & 0,7 & 0,6 & 3,7 \\
\hline Italy & 7,0 & 1,3 & $-6,3$ & $-3,1$ & 0,4 \\
\hline Canada & 4,8 & 3,9 & 1,0 & 1,6 & 2,8 \\
\hline United Kingdom (UK) & 2,8 & $-1,2$ & $-2,4$ & $-0,3$ & 0,8 \\
\hline US & 5,7 & 3,3 & 3,8 & 2,9 & 4,4 \\
\hline France & 5,2 & 2,2 & $-2,6$ & $-0,9$ & 0,8 \\
\hline Japan & 15,0 & $-2,9$ & 0,7 & $-0,9$ & 2,8 \\
\hline
\end{tabular}

